\title{
くい基礎工事における施工前並びに施工後の くい品質評価調査の試行について
}

\author{
林 隆浩*1 ・浅井 陽一*2 - 小野 日出男*3
}

\begin{abstract}
概 要 くい基礎の品質評価技術は，くいが地中に埋め込まれていることから非常に難しいとされてきた。しかしなが らコンクリートを媒体とした非破壊試験技術の発展に伴い幾つかの問題点を解決しょうとする動きも目立ち始めてきた。 このテクニカルレポートは，筆者らがこれまでの研究成果を実現場において実践する機会を得て 2 つ非破壊試験法によ りくい施工前と施工後の品質評価について実施したテストケースの報告である。

キーワード：非破壞, 品質評価, 超音波, 弾性波
\end{abstract}

1.はじめに

基礎構造の品質確保は，その確認方法む含めて非常に 難しい問題である。特に, 基礎構造の中でも地中深くに 設置されるくい基礎は，既設，新設を問わずその施工品 質扔よび支持力性能を的確にしかも経済的に確認するこ とは難しい。しかしながら，時代の流れは，上部構造の 大型化拈よび多様化によってより経済的で環境にやさし い安全性の高い基礎構造を要求している。これらを背景 として, 10 数年前に上部構造物の設計に限界状態設計 法が導入され，その構造規定が「仕様規定」から「性能 規定」へと移行し, さらに地盤工学の分野においても, 上部構造と基礎構造との調和のとれた安全性の議論が高 まり, 限界状態設計法導入の議論がなされ, その手法が 具体的に提示されはじめている。ただし，限界状態設計 法の導入に際しては多くの課題が残されており, 中でむ くい基礎構造の品質を確認・評価する技術の開発は, 解 決しなければならない重要な課題の一つである。

くい基礎においての品質管理は, 使用するくい材料の

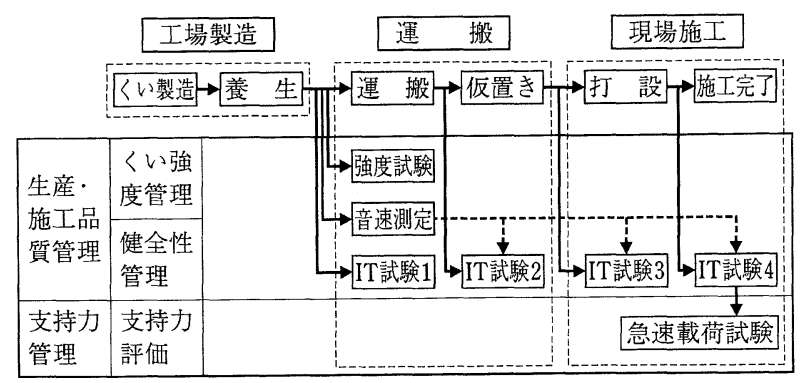

図-1 くいの総合品質管理システムの概要図 IT 試験：健全性試験

*1 はやし・たかひろ/愛知工業大学 建築学科 非常勤講師（婌トー ヨーアサノ 技術開発部 部長)（正会員）

*2 あさい・よういち/潹トーヨーアサノ 技術部

*3 おの・ひでお/侏東京ソイルリサーチ 総合企画部 部長 (正会員)
品質の確保と, 地盤中に施工されたくい基礎自体の品質 確保が必要であると考えられる。現状でのくい基礎の品 質管理手法は，くい製品としての管理が JIS に定めら れたロットによる代表管理であり，施工後のくい（以下， 施工ぐいとする）としての管理は施工に関わる工程管理 となる間接管理である。

これらの点を踏まえて, 本レポートでは, これまで筆 者らが提案してきた既製コンクリートぐい（埋込みぐい） を対象とした総合的な品質管理手法，すなわち図-1に 示す生産・施工品質管理について当該現場で使用される 全ぐいの工場搬出から現場搬入までのくい自体の品質確 認調查と調查結果の保存, 更には施工ぐいの健全性調査 を行った報告である。本調查は, くい材料の品質管理と 施工ぐい自体の品質管理を 2 種類の非破壊試験法を用い てテストケースとして実施している。

\section{2. 調查の背景と目的}

平成 11 年に施行された改正建築基準法に示された性 能評価型の設計への移行をスムーズに行うための環境整

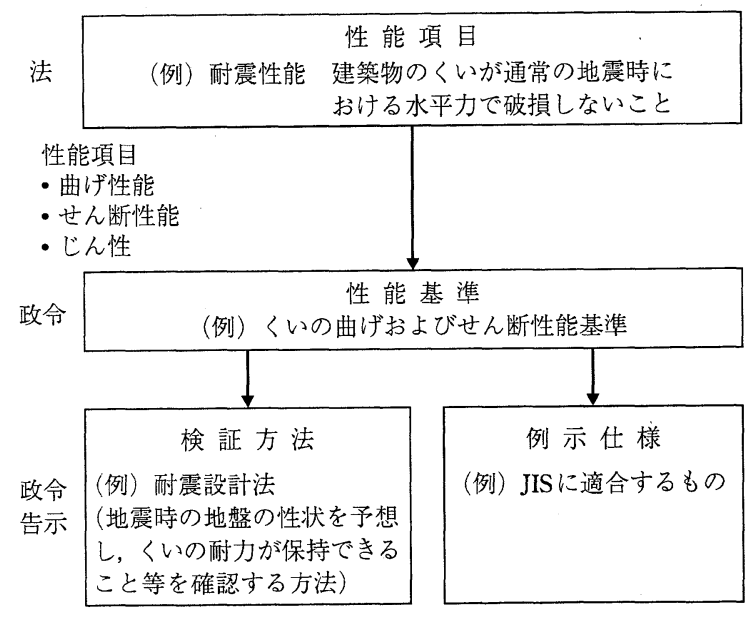

図-2 新たな建築基準の体系 
備が重要な課題となっている。この課題には，ユーザー, 設計者, 総合建設業者および各専門業者が一体となり解 決しなければならない点が多くある。そこで建設省や各 行政庁が，1つの手法として各部位の性能を表示するルー ル作りを模索し, 平成 9 年から建設省総合技術開発プロ ジェクトとして「建設事業の品質管理体系の開発」が進 められている。この体系の基本概念は，図-2 に示すと おりで図中の性能項目を満足する性能基準が定められる。 言わばこれが要求性能となり,この性能を確認あるいは 保証するための検証方法を明示し，これによって得られ た結果をユーザーに積極的に表示しょうとするものであ る。

この考え方を実施する具体策として当現場の発注者で ある東京都ならびに当設計・監理主体は，〈い材料の品 質管理として現場に搬入されたくい自体が，所定の圧縮 強度を保有しているから゙うかを供試体の圧縮試験で確認 し，併せて供試体とくいとで実施した音速の測定値を品 質のばらつきとして考慮できないかの検討も行った。ま た，施工ぐいのくい体連続性および損傷などをチェック するため, 衝撃弾性波を用いたくいの健全性調查を試行 したものである。さらに，これらのデー夕を当現場で施 工ぐいの履歴書として将来のために保存することも目的 とした。

\section{3. 調査の概要}

当現場における調查概要を以下に示す。調查を実施し た対象メーカーは，5社で全施工本数の扔扔よそ $20 \%$ について調査を行っている。

（1）調查件名：東京都高齢者福祉・医療の総合施設 （仮称）高齢者専門病院建設工事 くいの超音波試験・健全性試験

（2）調查場所：東京都江東区新砂 3 丁目地内

（3）調查期間：自 平成 11 年 10 月 26 日 至 平成 12 年 1 月 27 日（現場調查 期間)

（4）調査内容：くいの超音波試験および健全性試験 の概要は，以下に示すとおりである。

(1) くい体超音波試験

（i） 圧縮試験用遠心供試体 ……3 供試体（3 供試体 $\times 2$ 回 $\times 5$ 社 $)$ （ii）〈い単体（現場搬入時）

$$
\text { ……120 本（24 セット） }
$$

(2) くいの健全性試験

（i）くい単体（現場搬入時）

……313 本 (B 種 62 本 $+\mathrm{C}$ 種 251 本)

（ii）施工ぐい

……合計延べ 140 セット（98 セット；施 工直後 +42 セット; 掘削後)

4. 試験方法

試験方法は，〈い体コンクリートの品質調査を目的と した超音波試験とくい体（施工前後）の健全性調查を目 的とした衝撃弾性波試験の 2 種類である。試験対象とし たくいは，表-1に示す高強度プレストレストぐい （PHCぐい）のくい径 $1000 \mathrm{~mm}$ ，くい長 60 65 m で

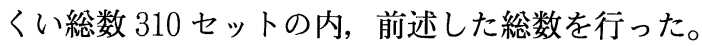

各試験法の詳細については，以下に記述したと扔りで ある。

\section{1 くいの超音波試験}

現場に搬入されたくいと圧縮試験用の遠心供試体に関 して超音波測定を行い，コンクリート中を伝搬する音速 之遠心供試体の压縮強度との相関性加ら，実際に使用す るくいの圧縮強度の推定を行った。

試験装置は，既存建築物の構造体コンクリートの強度 推定に用いられ，ある程度の実績がある超音波測定器を 使用した（写真-1 参照)。くい体の超音波測定は，図-3 に示すように, くい頭から 20〜30 cm 程度入ったくい コンクリート部のくい外表面と中空部内面に測定器のセ

表-1 くい仕様一覧

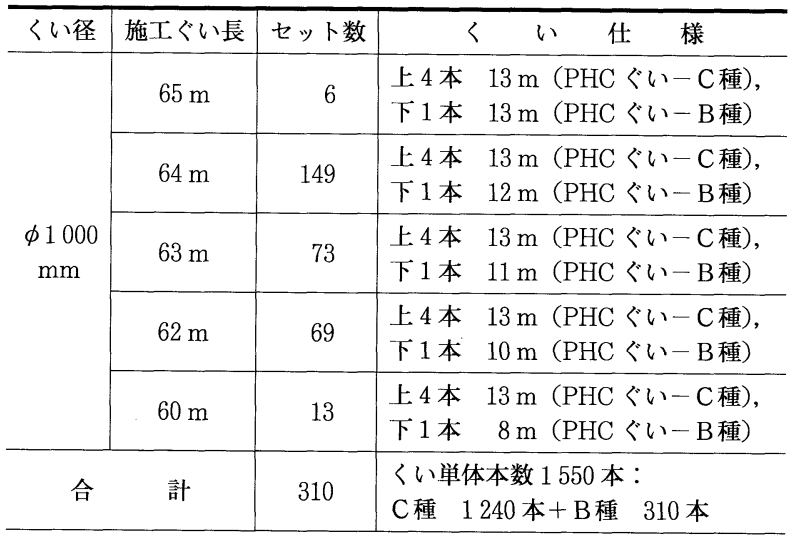

Test Case of Quality Assurance in Pile Foundation By T. Hayashi, Y. Asai and H. Ono

Concrete Journal, Vol. 39, No. 3, pp. 29 35, Mar. 2001

Synopsis Because pile is buried in the underground as for the quality evaluation of pile foundation, it is very difficult. However, there is movement to problem solution with development of non-destructive testing technology for concrete, too. This is the report that I did that the writers practice conventional study result in realization ground.

Keywords : non-destructive, quality assurance, elastic wave 
ンサーを設置し，その距離（壁厚）と超音波の到達時間 から伝搬速度を求めた（写真-3 参照）。

また，遠心供試体の場合にも，同図と同じように供試 体にセンサーを設置して, 供試体の超音波速度を求めた。 これらの測定結果から，〈い体のコンクリート中を伝搬 する超音波速度と圧縮強度の相関性を求め, 〈い体強度 の推定を行った（写真-2 参照）。

\section{2 くいの健全性試験}

くいの健全性試験は, 現場搬入時のくい単体での健全 性と施工ぐいの健全性を判定するために実施した。

弾性波を用いたくいの健全性試験は，オランダ製の装 置（IT-system）を用いて行った。図-4 は，現場での測

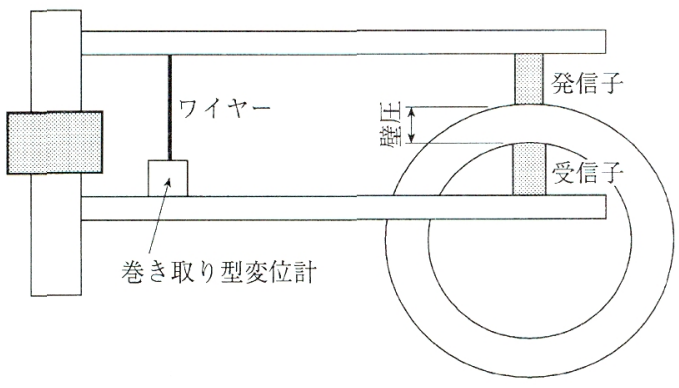

図-3 超音波試験測定方法

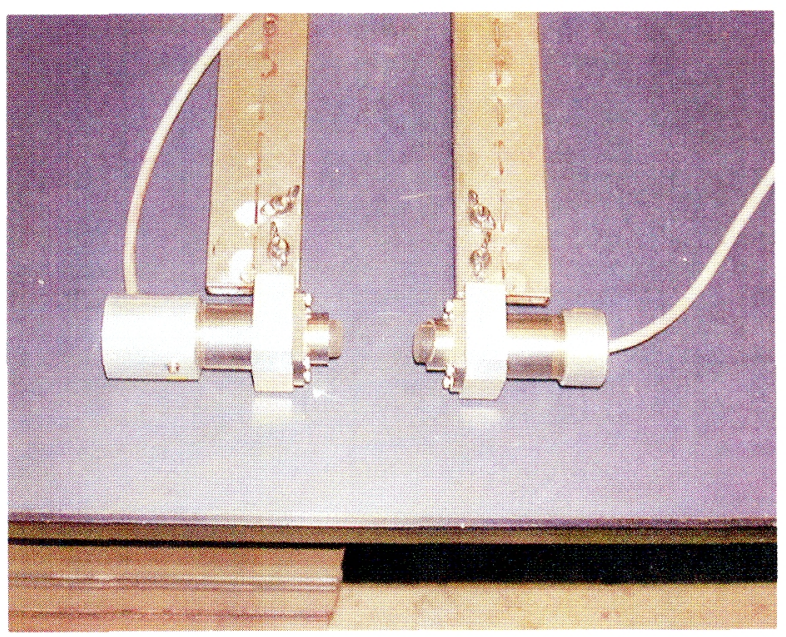

写真-1 超音波センサー

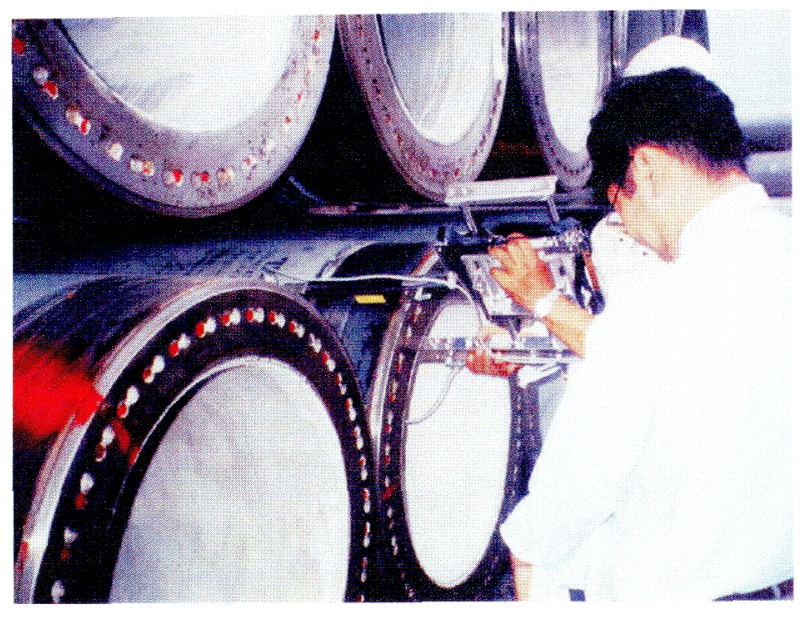

写真-3 くいの超音波試験計測状況
定から解析に至る本試験装置の概念を示したものである。 健全性試験の方法は，図に示すようにくい頭を小型の八 ンドハンマーで軽打し，その打撃により発生するパルス 波に対するくいの振動応答を，〈い頭に取り付けた加速 度計で測定するものである（写真-4 参照）。

試験装置は，測定された加速度信号に適当な周波数フィ ルターをかけることができ，〈い体を伝播する間の波動 減衰に対処するため，信号の増幅率を時間の経過ととも に大きくする構造となっている。1 回打撃するごとに，

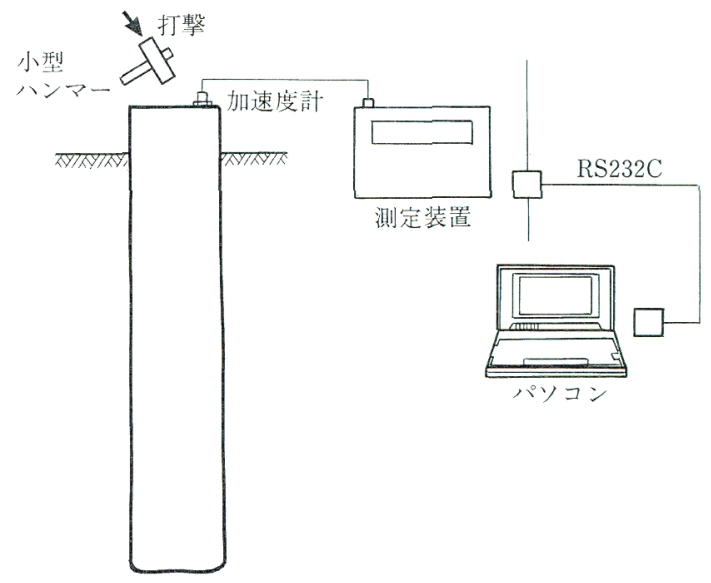

図-4 試験装置概要

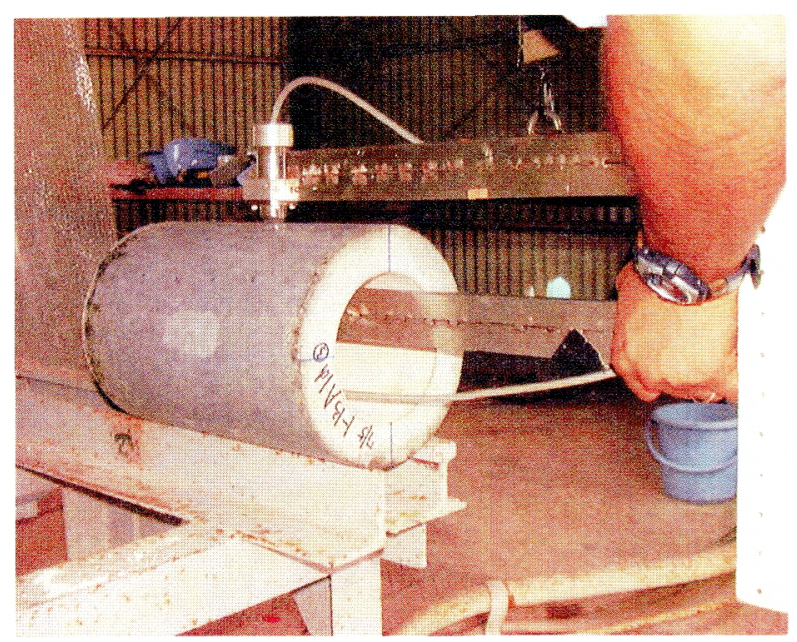

写真-2 遠心供試体の超音波試験計測状況

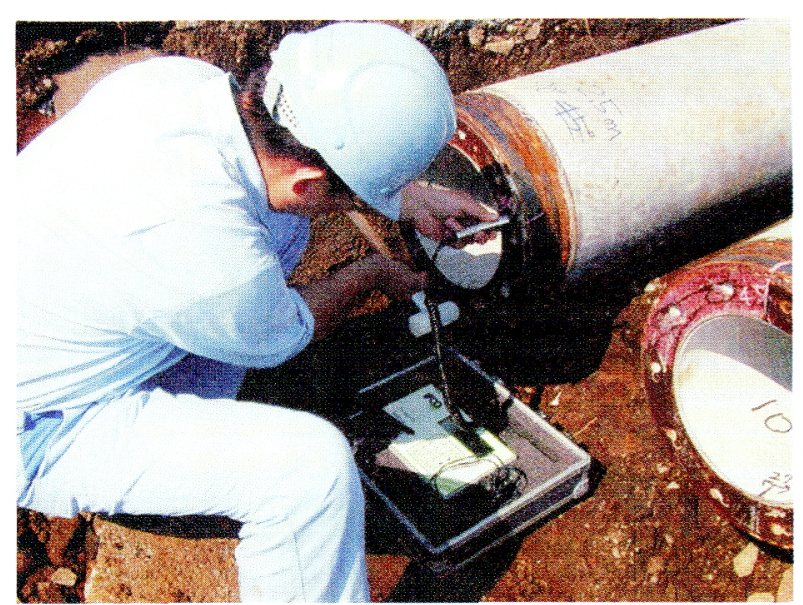

写真-4 くいの健全性試験 
くいの振動応答が試験装置にデジタル值として記録され る。実際のくいは，複合材料体で品質にばらつきがある ため, 加速度計の取付け位置やハンマーの打撃位置を適 切に選択する必要がある。そのため, 数回ないし場合に よっては数十回の試し打ちを行い，〈いの応答波形が安 定して得られる位置を選定し，再現性のある波形を数回 収録する。これは，信号に乗っている微小なノイズの影 響を除去し，応答信号を平均化するためである。図-5 に波動の伝播と応答波形の例を示す。

\section{5. 各試験実施の詳細}

超音波試験およびくいの健全性試験の実施数量と測定 日は，表-2〜表-5に示すとおりである。

\section{1 超音波試験}

超音波試験は，〈い体作製と同時に製作した圧縮試験 用の遠心供試体と, 現場搬入時のくい単体を対象として 実施した。各くいメーカーごとの測定日および実施数量 は，表-2 および表-3に示すとおりである。

（1）遠心供試体

遠心供試体の測定は，表-2に示すように，各メーカー 別に 3 供試体ずつ 2 回に分け，合計 30 供試体を現場に 搬入して実施した。超音波試験を実施した後, 压縮試験

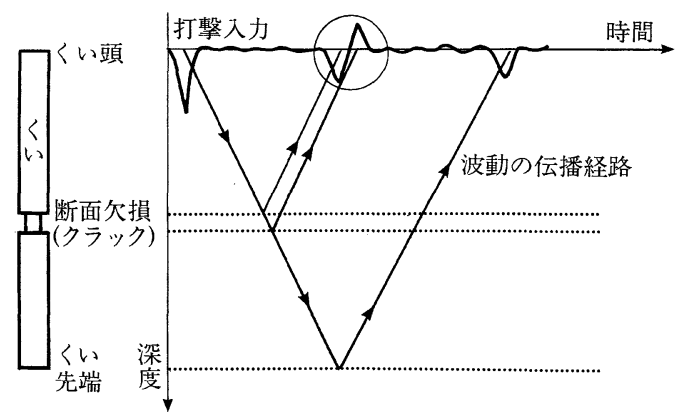

（1）断面欠損がある場合

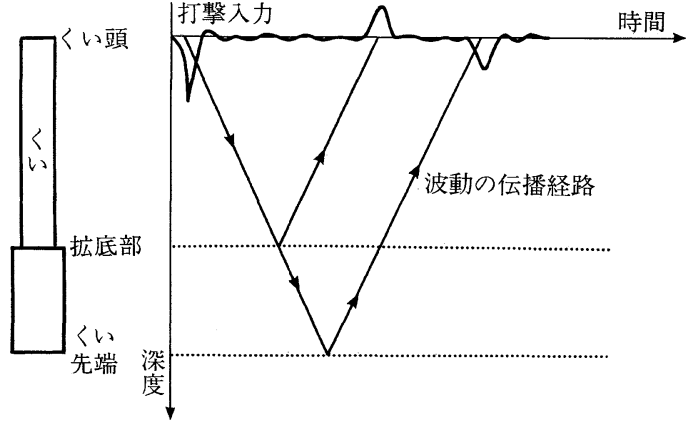

（2）断面拡大がある場合

図-5＼cjkstart波動の伝盤と応答波形

表-2 遠心供試体超音波試験実施数量一覧

\begin{tabular}{c|c|c|c|c|c|c}
\hline 測 定 日 & \multicolumn{5}{|c|}{ くいメーカー } & 合計（個） \\
\cline { 2 - 7 } (年月日) & A 社 & B 社 & C 社 & D 社 & E 社 & \\
\hline H 11.10.26 & 3 & 3 & 3 & 3 & 3 & 15 \\
\hline H 11.11.17 & 3 & 3 & 3 & 3 & 3 & 15 \\
\hline 合 計 (個) & 6 & 6 & 6 & 6 & 6 & 30 \\
\hline
\end{tabular}

を実施した。

\section{（2）〈い単体（現場搬入時）}

くい単体の超音波試験は, くい体現場搬入後の施工直 前に実施した。

\section{2 くいの健全性試験}

健全性試験は，〈い単体についてはくい体施工直前に 実施した。また，施工ぐいについては，施工直後に測定 が可能なものは直後に測定し，〈い頭が地中部にあり測 定できないものについては, 地盤掘削終了後に測定を行っ た。

\section{（1）〈い単体（現場搬入時）}

くい単体の健全性試験は，超音波試験と同様にくいの 施工直前に実施した。くい単体の測定日と測定本数は, 表-4に示すとおりである。

(2) 施工ぐい

施工ぐいの健全性試験は，合計 115 本の施工ぐいに関 して測定を実施した。このうち 11 本のくいについては, 施工後の時間経過による測定波形の変化を確認するため, 同一くいに関して2〜5 回の測定を実施した。

表-3 〈い単体超音波試験実施数量一覧（単位：本）

\begin{tabular}{|c|c|c|c|c|c|c|c|c|c|c|c|c|}
\hline \multirow{2}{*}{ 測定日 } & \multicolumn{2}{|c|}{ A 社 } & \multicolumn{2}{|c|}{$\mathrm{B} \quad$ 社 } & \multirow{2}{*}{\begin{tabular}{|c|c} 
& C \\
& B 種
\end{tabular}} & \multirow{2}{*}{ 社 } & \multirow{2}{*}{$\frac{\mathrm{D}}{\mathrm{B} \text { 種 }}$} & \multirow{2}{*}{\begin{tabular}{|l|}
\multicolumn{1}{c}{ 社 } \\
C 種
\end{tabular}} & \multicolumn{2}{|c|}{$\mathrm{E}$ 社 } & \multicolumn{2}{|c|}{ 合 計 } \\
\hline & B種 & C 種 & B 種 & C 種 & & & & & B種 & C 種 & B種 & $\mathrm{C}$ 種 \\
\hline $10 / 26$ & & & 1 & 4 & & & & & & & 1 & 4 \\
\hline $11 / 12$ & & & 1 & 4 & & & & & & & 1 & 4 \\
\hline $11 / 16$ & 1 & 4 & 1 & 4 & & & & & 1 & 4 & 3 & 12 \\
\hline $11 / 17$ & 1 & 4 & 2 & 8 & & & & & & & 3 & 12 \\
\hline $11 / 22$ & 3 & 12 & & & 2 & 8 & & & & & 5 & 20 \\
\hline $11 / 25$ & 1 & 4 & & & 2 & 8 & & & & & 3 & 12 \\
\hline $11 / 27$ & & & 1 & 4 & & & 2 & 8 & 1 & 4 & 4 & 16 \\
\hline $11 / 30$ & & & & & & & 2 & 8 & 1 & 4 & 3 & 12 \\
\hline $12 / 4$ & & & & & & & & & 1 & 4 & 1 & 4 \\
\hline 小 計 & 0 & 24 & 6 & 24 & 4 & 16 & 4 & 16 & 4 & 16 & 24 & 96 \\
\hline 合 計 & 3 & 0 & 3 & & 2 & 0 & 2 & & 2 & & 12 & \\
\hline
\end{tabular}

表-4 くい単体の健全性試験実施数量一覧（単位：本）

\begin{tabular}{|c|c|c|c|c|c|c|c|c|c|c|c|c|}
\hline \multirow{2}{*}{ 測定日 } & A & 社 & B & 社 & $\mathrm{C}$ & 社 & D & 社 & $\mathrm{E}$ & 社 & 合 & 計 \\
\hline & B種 & C 種 & B種 & C 種 & B種 & $\mathrm{C}$ 種 & B種 & C 種 & B種 & C 種 & B種 & C 種 \\
\hline $10 / 26$ & & & 1 & 4 & & & & & & & 1 & 4 \\
\hline $11 / 12$ & 1 & 5 & 2 & 8 & 1 & 5 & 1 & 4 & & & 5 & 22 \\
\hline $11 / 16$ & 1 & 4 & 1 & 4 & & & & & 1 & 4 & 3 & 12 \\
\hline $11 / 17$ & 1 & 4 & 2 & 8 & & & & & & & 3 & 12 \\
\hline $11 / 22$ & 3 & 12 & & & 3 & 12 & & & & & 6 & 24 \\
\hline $11 / 25$ & 4 & 16 & & & 3 & 12 & & & & & 7 & 28 \\
\hline $11 / 27$ & 2 & 9 & 2 & 8 & & & 1 & 4 & 1 & 4 & 6 & 25 \\
\hline $11 / 30$ & & & & & & & 1 & 4 & 1 & 4 & 2 & 8 \\
\hline $12 / 4$ & 2 & 8 & & & 2 & 8 & & & 1 & 4 & 5 & 20 \\
\hline $12 / 7$ & 3 & 12 & & & 3 & 12 & & & 2 & 8 & 8 & 32 \\
\hline $12 / 10$ & & & 4 & 16 & & & 2 & 8 & & & 6 & 24 \\
\hline $12 / 13$ & & & 6 & 24 & 2 & 8. & & & & & 8 & 32 \\
\hline $12 / 16$ & & & & & 1 & 4 & & & 1 & 4 & 2 & 8 \\
\hline 小 計 & 17 & 70 & 18 & 72 & 15 & 61 & 5 & 20 & 7 & 28 & 62 & 251 \\
\hline 合 計 & 87 & & 9 & & 7 & & 25 & & 3 & 5 & 31 & \\
\hline
\end{tabular}


表-5 は，施工後に健全性試験を実施したくいの施工 日と測定日の一覧を示したものである。

\section{6. 調 查 結果}

\section{1 超音波試験結果}

くい単体の超音波試験結果を表-6 と図-6 に示す。図 -6 は, メーカーごとの超音波速度の分布状況を示した
ものである。また，表-6 は，測定結果の最大值，最小 值および平均値を整理して示したものである。

測定結果によると, くい単体の超音波速度は, メ一カー ごとに若干のばらつきがみられるが，おおむね 4 200〜 $5100 \mathrm{~m} / \mathrm{sec}$ の範囲（平均值：4 453〜 4810 m/sec）に分 布しており，既製コンクリートぐいの一般な值に比べて 若干大きめの值を示している。

表-5 くい体施工後の健全性試験実施数量一覧

\begin{tabular}{|c|c|c|c|c|c|c|c|c|}
\hline No. & 施工日 & 測定日 & No. & 施工日 & 測定日 & No. & 施工日 & 測定日 \\
\hline 1 & $11 / 19$ & $11 / 25$ & 41 & $11 / 12$ & $11 / 25$ & 151 & $11 / 12$ & $1 / 26$ (掘削後) \\
\hline 2 & $11 / 20$ & $11 / 25$ & 44 & $11 / 11$ & (1)11/12(2)11/22 & 153 & $11 / 13$ & $1 / 26(" \prime)$ \\
\hline 3 & $11 / 19$ & $11 / 25$ & 49 & $11 / 11$ & (1) $11 / 12(2) 11 / 22$ & 160 & $12 / 13$ & $1 / 27(" \prime)$ \\
\hline 4 & $11 / 19$ & $11 / 25$ & 50 & $11 / 10$ & $11 / 22$ & 164 & $12 / 16$ & $1 / 27(" \prime)$ \\
\hline 5 & $11 / 15$ & $12 / 4$ & 51 & $11 / 10$ & $11 / 25$ & 166 & $12 / 15$ & $1 / 26(" \prime)$ \\
\hline 6 & $11 / 13$ & $12 / 4$ & 52 & $11 / 20$ & $11 / 25$ & 167 & $12 / 18$ & $1 / 26(" \prime)$ \\
\hline 7 & $11 / 13$ & $11 / 27$ & 53 & $11 / 20$ & $11 / 25$ & 176 & $12 / 21$ & $1 / 27(" \prime)$ \\
\hline 8 & $11 / 12$ & $11 / 27$ & 54 & $11 / 22$ & $11 / 25$ & 177 & $12 / 23$ & $1 / 27(" \prime)$ \\
\hline 9 & $11 / 12$ & $11 / 27$ & 55 & $11 / 22$ & $11 / 25$ & 180 & $11 / 15$ & $1 / 26(" \prime)$ \\
\hline 11 & $11 / 11$ & $11 / 16$ & 56 & $10 / 30$ & (1)11/12(2)11/25 & 184 & $11 / 13$ & $1 / 26(" \prime)$ \\
\hline 15 & $11 / 10$ & $11 / 12$ & 63 & $11 / 25$ & $12 / 4$ & 191 & $12 / 14$ & $1 / 27(" \prime)$ \\
\hline 16 & $11 / 9$ & (1)11/16(2)11/22 & 64 & $11 / 26$ & $12 / 4$ & 193 & $12 / 17$ & $1 / 27(" \prime)$ \\
\hline \multirow{3}{*}{17} & \multirow{3}{*}{$11 / 3$} & (1) $11 / 6$ (2)11/22 & 65 & $11 / 25$ & $12 / 4$ & 194 & $12 / 18$ & $1 / 26(" \prime)$ \\
\hline & & (3) $12 / 7$ (4) $12 / 13$ & 66 & $11 / 26$ & $12 / 7$ & 196 & $12 / 25$ & $1 / 27(" \prime)$ \\
\hline & & (5) $12 / 16$ & 67 & $11 / 27$ & $12 / 7$ & 200 & $12 / 24$ & $1 / 26(" \prime)$ \\
\hline \multirow{2}{*}{18} & \multirow{2}{*}{$11 / 8$} & (1) $11 / 12(2) 12 / 7$ & 68 & $11 / 27$ & $12 / 7$ & 205 & $12 / 22$ & $1 / 27(" \prime)$ \\
\hline & & (3)12/13(4)12/16 & 69 & $11 / 29$ & $12 / 7$ & 208 & $12 / 21$ & $1 / 27(" \prime)$ \\
\hline \multirow{3}{*}{19} & \multirow{3}{*}{$11 / 6$} & (1)11/12(2)11/22 & 70 & $11 / 27$ & $12 / 7$ & 211 & $11 / 17$ & $1 / 26(" \prime)$ \\
\hline & & (3) $12 / 7$ (4) $12 / 13$ & 71 & $11 / 29$ & $12 / 7$ & 215 & $11 / 18$ & $1 / 26(" \prime)$ \\
\hline & & (5)12/16 & 73 & $11 / 25$ & $11 / 27$ & 220 & $12 / 11$ & $1 / 27(" \prime)$ \\
\hline \multirow{3}{*}{20} & \multirow{3}{*}{$11 / 6$} & (1) $11 / 12(2) 11 / 22$ & 74 & $11 / 26$ & $11 / 27$ & 221 & $12 / 18$ & $1 / 27(" \prime)$ \\
\hline & & (3) $12 / 7$ (4) $12 / 13$ & 75 & $11 / 25$ & $11 / 27$ & 224 & $12 / 17$ & $1 / 26(" \prime)$ \\
\hline & & (5) $12 / 16$ & 76 & $11 / 25$ & $11 / 27$ & 226 & $12 / 20$ & $1 / 27(" \prime)$ \\
\hline 21 & $11 / 5$ & (1) $11 / 6$ (2)11/22 & 77 & $11 / 23$ & $11 / 27$ & 230 & $12 / 17$ & $1 / 26(" \prime)$ \\
\hline \multirow{2}{*}{22} & \multirow{2}{*}{$11 / 4$} & (1) $11 / 6$ (2)11/22 & 82 & $11 / 20$ & $11 / 27$ & 236 & $12 / 14$ & $1 / 27(" \prime)$ \\
\hline & & (3)12/7 (4)12/13 & 83 & $11 / 20$ & $11 / 27$ & 242 & $11 / 4$ & $1 / 26(" \prime)$ \\
\hline \multirow{2}{*}{23} & \multirow{2}{*}{$11 / 3$} & (1) $11 / 6$ (2)11/22 & 85 & $11 / 19$ & $11 / 27$ & 246 & $10 / 30$ & $1 / 26(" \prime)$ \\
\hline & & (3) $12 / 13$ & 86 & $11 / 20$ & $11 / 27$ & 250 & $11 / 6$ & $1 / 26(" \prime)$ \\
\hline 24 & $11 / 19$ & $11 / 22$ & 102 & $12 / 1$ & $12 / 7$ & 255 & $11 / 8$ & $1 / 26(" \prime)$ \\
\hline 25 & $11 / 19$ & $11 / 25$ & 103 & $12 / 1$ & $12 / 7$ & 261 & $12 / 9$ & $1 / 26(" \prime)$ \\
\hline 26 & $11 / 18$ & $11 / 22$ & 104 & $12 / 1$ & $12 / 7$ & 266 & $12 / 7$ & $1 / 26(" \prime)$ \\
\hline 27 & $11 / 18$ & $11 / 25$ & 109 & $11 / 29$ & $12 / 7$ & 269 & $12 / 6$ & $1 / 26(" \prime)$ \\
\hline 28 & $11 / 18$ & $11 / 25$ & 112 & $12 / 1$ & $12 / 10$ & 274 & $11 / 19$ & $1 / 26(" \prime)$ \\
\hline 30 & $11 / 17$ & $11 / 22$ & 113 & $11 / 30$ & $12 / 10$ & 289 & $12 / 2$ & $1 / 26(" \prime)$ \\
\hline 31 & $11 / 17$ & $11 / 25$ & 114 & $12 / 1$ & $12 / 10$ & 292 & $11 / 1$ & $1 / 26(" \prime)$ \\
\hline 32 & $11 / 16$ & $11 / 25$ & 119 & $12 / 6$ & $12 / 10$ & 295 & $12 / 4$ & $1 / 26(" \prime)$ \\
\hline 35 & $11 / 15$ & $11 / 25$ & 120 & $12 / 4$ & $12 / 10$ & 300 & $11 / 22$ & $1 / 26(" \prime)$ \\
\hline 36 & $11 / 16$ & $11 / 25$ & 121 & $12 / 6$ & $12 / 10$ & 301 & $11 / 23$ & $1 / 26(" \prime)$ \\
\hline 37 & $11 / 12$ & $11 / 25$ & 122 & $12 / 6$ & $12 / 10$ & 303 & $1 / 24$ & $1 / 26(" \prime)$ \\
\hline 38 & $11 / 13$ & $11 / 25$ & 123 & $12 / 6$ & $12 / 10$ & 307 & $11 / 26$ & $1 / 26(" \prime)$ \\
\hline 39 & $11 / 13$ & $11 / 25$ & 147 & $12 / 14$ & 1/26（掘削後） & - & - & - \\
\hline 40 & $11 / 12$ & $11 / 25$ & 148 & $12 / 15$ & $1 / 26(" \prime)$ & - & - & - \\
\hline 小計 & 33本 & 延 55 本 & 小計 & 42 本 & 延 45 本 & 小計 & 40 本 & 延 40 本 \\
\hline \multicolumn{2}{|c|}{ 測定くい合計 } & \multicolumn{3}{|c|}{115 本 } & 延測定くい合計 & \multicolumn{3}{|c|}{140 本 } \\
\hline
\end{tabular}


一方, 压縮試験用供試体の超音波速度と压縮強度の測 定結果は，図-7に示すとおりである。圧縮供試体の超 音波速度は, 4 269 $5475 \mathrm{~m} / \mathrm{sec}$ の範囲に分布して抢り, 実際のくい単体での測定結果よりもわずかに大き目の值 となっている。特に，2 回目の測定結果（11月 17 日実 施）が， $4650 \mathrm{~m} / \mathrm{sec}$ 以上の大きな値を示している。 図-7 に示す供試体の圧縮強度との相関では, 超音波之 有為性はみられない。しかしながら各社ごとの調査日別 でのこの相関性は, 有為性がうかがえ音速ならびに強度 とも大きなばらつきはみられず，強度では，82.9〜98.5 $\mathrm{N} / \mathrm{mm}^{2}$ の範囲（平均値：91. $1 \mathrm{~N} / \mathrm{mm}^{2}$ ) に分布し, 各 社別の音速のばらつきも $5 \%$ 程度小さい。

表-6 〈い単体の超音波試験結果一覧

\begin{tabular}{|c|c|c|c|c|c|c|c|}
\hline \multirow{2}{*}{$\begin{array}{l}<\quad \text { } \\
x-カ ー\end{array}$} & \multirow{2}{*}{\multicolumn{2}{|c|}{ くい種 }} & \multirow{3}{*}{\begin{tabular}{|c}
$\begin{array}{l}\text { 测定くい } \\
\text { 本数（本） }\end{array}$ \\
6
\end{tabular}} & \multicolumn{4}{|c|}{ 超音波速度 $(\mathrm{m} / \mathrm{sec})$} \\
\hline & & & & 最小值 & \multirow{2}{*}{$\frac{\text { 最大値 }}{4.476}$} & \multicolumn{2}{|c|}{ 平均値 } \\
\hline \multirow{2}{*}{$A$ 社 } & B & 種 & & 4392 & & 4434 & \multirow{2}{*}{4453} \\
\hline & & 種 & 24 & 4067 & 4779 & 4458 & \\
\hline \multirow{2}{*}{$B$ 社 } & & 種 & 6 & 4417 & 4926 & 4637 & \multirow{2}{*}{4634} \\
\hline & & 種 & 24 & 4282 & 5013 & 4633 & \\
\hline \multirow{2}{*}{$C$ 社 } & & 種 & 4 & 4281 & 4899 & 4618 & \multirow{2}{*}{4607} \\
\hline & & 種 & 16 & 4204 & 4927 & 4605 & \\
\hline \multirow{2}{*}{ D 社 } & & 種 & 4 & 4567 & 5170 & 4821 & \multirow{2}{*}{4810} \\
\hline & & 種 & 16 & 4572 & 5118 & 4808 & \\
\hline \multirow{2}{*}{$\mathrm{E}$ 社 } & & 種 & 4 & 4495 & 4939 & 4680 & \multirow{2}{*}{4675} \\
\hline & $\mathrm{C}$ & 種 & 16 & 4419 & 5118 & 4674 & \\
\hline
\end{tabular}

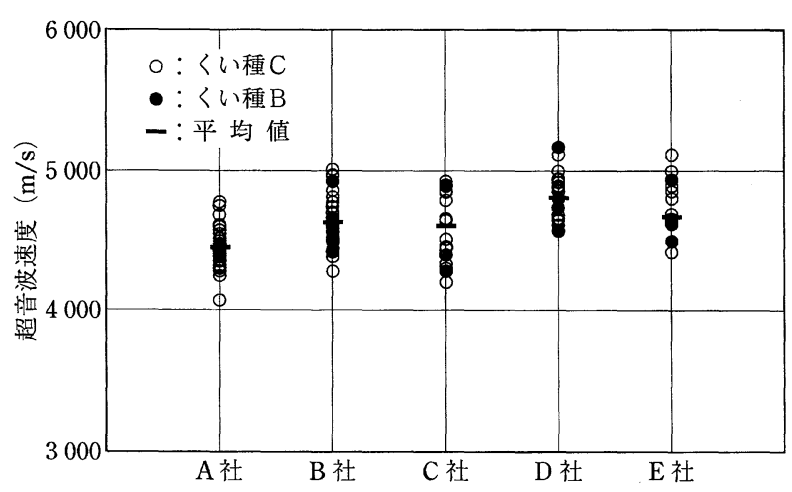

図-6 くい単体超音波速度のメーカー別分布図

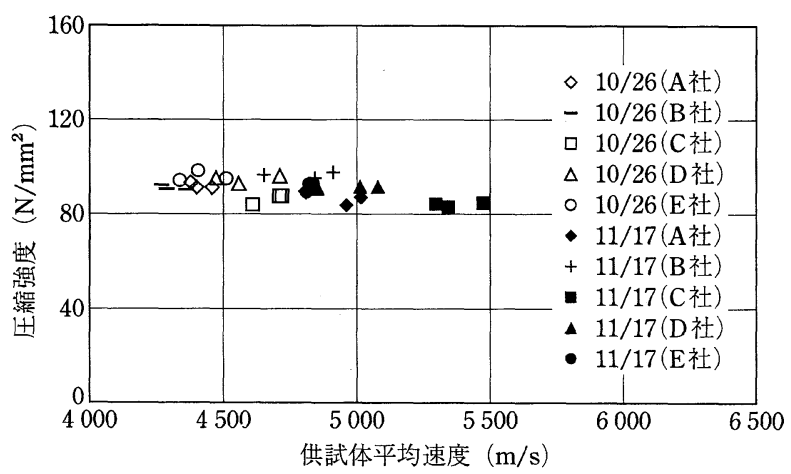

図-7 供試体超音波平均速度と圧縮強度の関係

\section{2 くいの健全性試験結果}

（1）〈い単体の健全性試験結果

前述の超音波試験によると, くい体の超音波速度は, お打む权 4 200 $5100 \mathrm{~m} / \mathrm{sec}$ の範囲に分布しており, 全 体平均 $4620 \mathrm{~m} / \mathrm{sec}$ の結果が得られた。筆者らの過去の 研究によれば, くい体の弾性波速度は, 超音波速度より 屯約 $5 \%$ 前後小さくなることが報告されている1)。そこ で, 今回の健全性試験では, くい体の弾性波速度を超音 波速度（全体平均）のほぼ $95 \%$ にあたる $4400 \mathrm{~m} / \mathrm{sec}$ として測定を実施した。

測定は, 各くいメーカーごとの使用数量を考慮して, B 種 62 本, $\mathrm{C}$ 種 251 本の合計 313 本について実施した。 健全性試験の測定結果一例は, 図-8の「くい単体の健 全性試験測定結果例」に示すとおりである。

波形の判定については，以下の基準を考慮して行った。

(1) くい頭付近の反射波形の内, 打撃直後の波形の特 徵

(2) くい頭付近の反射波形の内, 打撃直後の波形に続 く波形の特徴

(3) 繰返し波形の有無

(4) 中間部に下向きの大きなピークがある場合

(5) くい先端のピークの位置

(6) くい先端のピークの明瞭さ

(7) くい先端のピークの大きさ

測定結果によると，測定を実施した計 313 本のすべて のくいは，途中に損傷を示すような異常な反射は認めら れず，くい体はすべて健全であることが確認された。先 端反射の位置は，くいの実長とほぼ一致しており，くい 体の弾性波速度は, 測定時に設定した $4400 \mathrm{~m} / \mathrm{sec}$ 前後 であると推定される。

（2）〈い体施工後の健全性試験結果

地盤中に施工された後の既製ぐいの健全性試験では, 周辺地盤の拘束圧やくい体の周面摩擦力などの影響によっ て, くい体の伝播速度が気中での速度よりも若干小さく なることが定性的に知られている。経験的には，既製コ ンクリートぐいの地中での弾性波速度は, 一般に 4000 $\sim 4400 \mathrm{~m} / \mathrm{sec}$ 程度の值が採用されている。今回の調查 で用いたくい体の弾性波速度は, 単体で用いた速度より

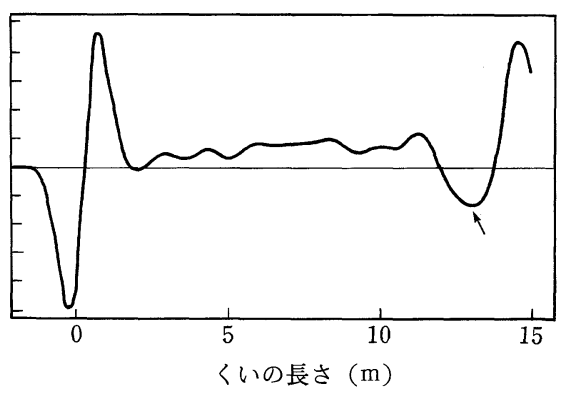

図-8 くい単体の健全性試験測定結果例 （良好な波形） 


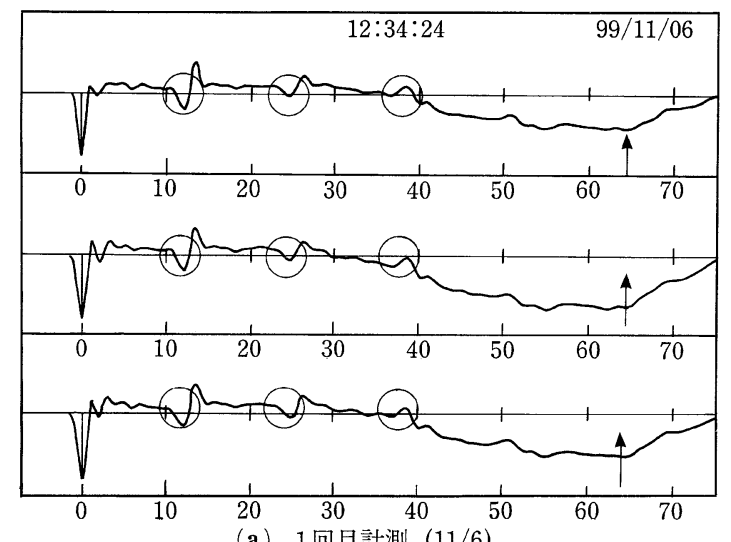

(a) 1 回目計測 $(11 / 6)$

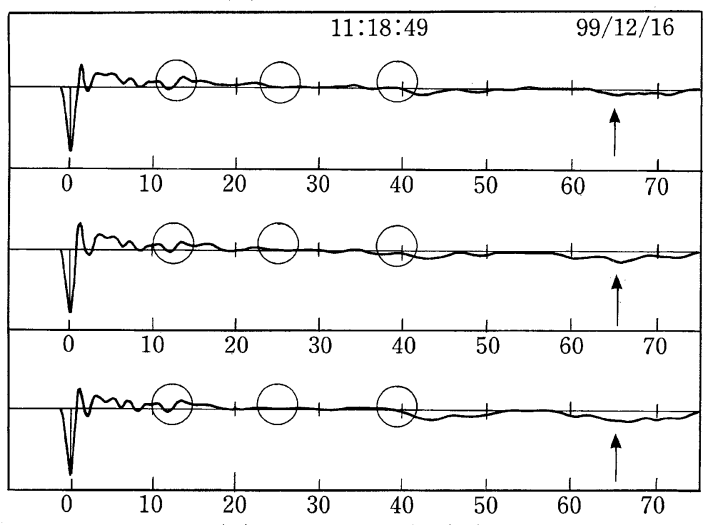

(b) 5 回目計測 $(12 / 16)$

注） $\bigcirc$ : 継手, $\uparrow:$ 先端位置

図-9 測定波形例

$5 \%$ 程度小さい $4200 \mathrm{~m} / \mathrm{sec}$ を採用した。

測定は，合計 115 本の施工ぐいを 13 回に分けて実施 した。このうち, 11 本のくいについては, 施工後の時 間経過による測定波形の変化を把握するため, 複数回の 測定を実施しており，延べ 140 本のくいについて測定を 実施した。また原則として，施工後出来るだけ早い時期 に測定を実施することとした。しかし，No. 147 以降の くいに関しては，〈いの施工完了時にくい頭が埋設され てしまうため，地盤の掘削完了後に測定を実施した。 （図-9 測定波形参照）

測定結果によると，測定を行った計 115 本のくいにつ いては，〈い体の途中に損傷を示すような異常な反射は 認められず，いずれのくい屯健全であると推定される。 今回，測定された波形の特徵は，下記のとおりである。

(1) ほとんどのくいで，最上部の継ぎ手部分からの反 射は明瞭に確認されているが，それ以深ではあまり 明瞭には現れない。ただし，管内土の少ないくいに 関しては，以深の継ぎ手からの反射も明瞭に現れて いる。
(2) くい頭付近に，端板あるいは鉄筋などの振動によ る高周波ノイズを含む波がみられるくいがある。

(3) 先端反射は, くい長が長いため, 通常短いくいに みられるような明瞭な反射形状とはなっていないが, 施工後 24 時間以内程度の早い時期に測定したくい では，比較的明瞭な先端反射が確認される傾向があ る。したがって，地盤掘削後のくいに関しては，施 工からの時間経過が長いため先端反射は不明瞭のも のが多い。

(4) 先端反射深度は, くいの弾性波速度を $4200 \mathrm{~m} /$ sec の一定値と設定して場合のものであり，実際の くいは地中部での拘束圧や周面摩擦力などの影響に よって速度が変化するため，ある程度の䛊差を生じ るものと考えられる。

7. まと め

実施工現場において，総合品質管理システムのテスト ケースとして実施した結果について以下に示す。

（1）各メーカーの同一工場で製造されたくい体コン クリートでの超音波試験の伝播速度は，〈い単体 および遠心供試体とも大きなばらつきはなくほぼ 同程度のばらつきとなっており品質が比較的安定 していると考えられる。

（2）図-1 に示す総合管理システムの I. T 試験 1，2 および 3 での各時期に実施した結果，運搬，施工 後の健全性調査で健全であることが確認された。 よって施工時でのトラブル発生がなかったことを 証明した事になろう。

以上の結果から今回提案した総合管理システムを効果 的に利用することで製造から施工後までの一貫管理が可 能となると考えられる。

謝 辞 当レポートの記載にあたり，東京都，(陎磯崎 新アトリ工，鹿島・大成・前田・飛島・トピー建設共同 企業体ならびに東京ソイルリサーチ社より多大なご協力 を得ましたことについて紙面を借りて心から御礼を申し 上げます。

参 考 文 献

1）林ほか：非破壊試験を用いた既製コンクリート杭の総合的品質管 理の提案, 日本建築学会大会学術講演概要集 (関東), pp. 241 242, 1993

2）田村・堀井・藤井：建築における埋込み杭の設計と施工，基礎工, pp. $18 \sim 23,1998.2$

3）林：愛知工業大学博士論文，1996 